\title{
Klippel-Trenaunay-Weber syndrome as a cause of chronic thromboembolic pulmonary hypertension
}

\author{
Jirat Chenbhanich, ${ }^{1}$ Nophol Leelayuwatanakul, ${ }^{2}$ Prasit Phowthongkum ${ }^{3,4}$
}

'Department of Internal Medicine, Metrowest Medical Center, Framingham, Massachusetts, USA ${ }^{2}$ Division of Pulmonary and Critical Care Medicine, Department of Medicine, Faculty of Medicine, Chulalongkorn University, Bangkok, Thailand ${ }^{3}$ Division of Medical Genetics and Genomics, Department of Medicine, Faculty of Medicine, Chulalongkorn University, Bangkok, Thailand

${ }^{4}$ Adult Cardiovascular Genetic Clinic, King Chulalongkorn Memorial Hospital, Thai Red Cross Society, Bangkok, Thailand

\section{Correspondence to}

Dr Jirat Chenbhanich, jirat.chen@yahoo.com

Accepted 10 March 2018

\section{DESCRIPTION}

A 52-year-old man was referred to an adult cardiovascular genetic clinic for lifelong venous tortuosity of the left leg. His medical history included recurrent deep venous thromboses of the left leg and pulmonary embolism complicated by oxygen-dependent chronic thromboembolic pulmonary hypertension and right-sided heart failure. He was taking warfarin and reported no family history of similar conditions. On examination, crackles were noted at bibasilar lungs. The left leg was slightly longer than the right leg, and giant tortuous veins were observed on the left side (figure 1A). MRI and angiography of the lower extremities revealed diffuse muscular hypertrophy (figure 1B) and bone elongation of the femur, tibia and fibula, as well as multiple capillary-venous malformations and tortuous deep and superficial veins (figure 1C) on the left leg. Chest tomography angiography showed pulmonary artery dilatation and calcified eccentric thrombus in the right pulmonary artery, consistent with chronic thromboembolic pulmonary hypertension (figure 2). There was no evidence of pulmonary arteriovenous malformation.

A diagnosis of Klippel-Trenaunay-Weber syndrome (KTWS) was made. It is characterised by congenital vascular malformations, varicose veins and a localised disturbed growth of the bone and/or soft tissues, resulting in

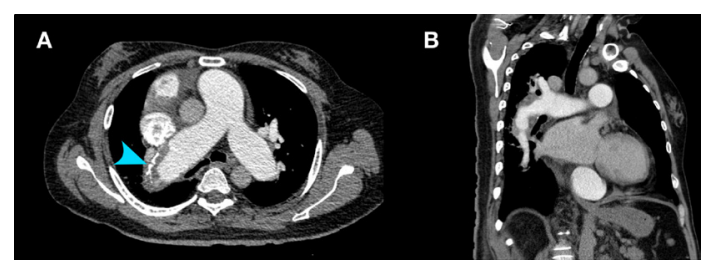

Figure 2 Chest tomography angiography, axial view (A) and sagittal view $(B)$, showing pulmonary artery dilatation and calcified eccentric thrombus (arrowhead) in the right pulmonary artery, consistent with chronic thromboembolic pulmonary hypertension.

limb length discrepancy. Its estimated prevalence is 1 in 20000 to 1 in 100000 live births. ${ }^{1}$ Varicosities are more prominent during adolescence and affect both superficial and deep veins. ${ }^{1}$ Venous thromboembolism is common in patients

Learning points

- Klippel-Trenaunay-Weber syndrome (KTWS) is characterised by congenital vascular malformations, varicose veins and a localised disturbed growth of the bone and/or soft tissues.

- KTWS may result in recurrent venous thromboembolism due to malformed vessels and is a rare cause of chronic thromboembolic pulmonary hypertension. 
with KTWS due to localised intravascular thromboses within the malformed vessels; these can embolise and result in pulmonary embolism and subsequent chronic thromboembolic pulmonary hypertension. ${ }^{2}$ Other thoracic pathologies observed in KTWS include venous malformations of the chest wall and pulmonary arteriolar aneurysm. ${ }^{2}$ Most cases are sporadic and it was hypothesised that the condition is caused by somatic mutation. Recent studies have demonstrated somatic mosaicism of the PIK3CA gene in the affected limbs in some individuals; targeted therapy inhibiting PI3KAKT-mTOR signalling pathway, which is aberrantly activated in PIK3CA activating mutation, might therefore be a future option for treatment of KTWS and similar disorders. ${ }^{2}{ }^{3}$ As the diagnosis was made for the patient, the prognosis and the management plan can be established for chronic thromboembolic pulmonary hypertension associated with KTWS, without further invasive diagnostic investigation. Furthermore, the somatic mutation nature of the disease indicated that the recurrence risk in family members and offspring is negligible. We thus continued conservative treatment for varicosities, chronic thromboembolic pulmonary hypertension and right-sided heart failure.
Contributors Conception and design, interpretation of data and approval of the final version of the manuscript: JC, NL and PP. Acquisition of data and drafting the manuscript: JC and NL. Revision of the manuscript: PP.

Funding The authors have not declared a specific grant for this research from any funding agency in the public, commercial or not-for-profit sectors.

Competing interests None declared.

Patient consent Obtained.

Provenance and peer review Not commissioned; externally peer reviewed.

(C) BMJ Publishing Group Ltd (unless otherwise stated in the text of the article) 2018. All rights reserved. No commercial use is permitted unless otherwise expressly granted.

\section{REFERENCES}

1 Lacerda LS, Alves UD, Zanier JF, et al. Differential diagnoses of overgrowth syndromes: the most important clinical and radiological disease manifestations. Radiol Res Pract 2014;2014:1-7.

2 Hammer MM, Miller WT. Thoracic Manifestations of Klippel-Trenaunay Syndrome. J Thorac Imaging 2017;32:W5-W6.

3 Vahidnezhad H, Youssefian L, Uitto J. Klippel-Trenaunay syndrome belongs to the PIK3CA-related overgrowth spectrum (PROS). Exp Dermatol 2016;25:17-19.

Copyright 2018 BMJ Publishing Group. All rights reserved. For permission to reuse any of this content visit

http://group.bmj.com/group/rights-licensing/permissions.

BMJ Case Report Fellows may re-use this article for personal use and teaching without any further permission.

Become a Fellow of BMJ Case Reports today and you can:

- Submit as many cases as you like

- Enjoy fast sympathetic peer review and rapid publication of accepted articles

- Access all the published articles

- Re-use any of the published material for personal use and teaching without further permission

For information on Institutional Fellowships contact consortiasales@bmjgroup.com

Visit casereports.bmj.com for more articles like this and to become a Fellow 